\title{
ANALISIS DESAIN IKLAN DENGAN PENDEKATAN BUDAYA MENURUT KRITERIA EVALUASI KONSUMEN DI KOTA MATARAM (STUDI KASUS IKLAN TELKOMSEL BERNUANSA BUDAYA SASAK)
}

\author{
Lalu Adi Permadi * \\ G A Sri Oktaryani *) \\ H. Muhammad Ilhamuddin *) \\ Dedy Iswanto **)
}

\begin{abstract}
The purpose of this study is to determine suitable design of the Telkomsel culture approach ad by using the evaluation criteria the consumer of Sasak ethnic in Mataram. Methodologically, to prove the purpose of the study was using Mixed Methods Research that consisting of Focus-Group Research, and in-depth interviews,. The results of this study showed that the ideal design of Telkomsel's advertising design nuanced cultural according to consumers' evaluation criteria with the following attributes 1) Color; 2) Picture: Art and Cultural Events Other Sasak; 3) Information Features and Amenities: Features And major addition; 4) slogan: Relating to Identity Lombok Island, 5) information Price: Clearly in Any feature Promoted; 6) Size: Extra Large; 7) Media: Advertising Signage /Billboards Or Banners and 8) ad Location: Population in Each place Solid.
\end{abstract}

Keywords: design, advertising, culture approach, consumer evaluation criteria

\section{PENDAHULUAN}

Iklan sebagai bagian dari bauran promosi dewasa ini sangat penting bagi kegiatan pemasaran. Menurut Dharmmesta dan Irawan (2001 : 349) promosi secara umum bertujuan untuk menginformasikan, mempengaruhi, dan membujuk serta mengingatkan pelanggan sasaran tentang pemasaran dan bauran pemasaran. Untuk itu maka saat ini kehidupan manusia sebagai subyek dan obyek dari pemasaran selalu dikelilingi oleh iklan.

Periklanan saat ini telah menjadi bagian dari sebuah sistem perekonomian. Karena perusahaan yang ingin mengiklankan produknya menggunakan biro iklan untuk membuat iklan dan media sebagai penyampai pesan iklan seperti surat kabar, televisi dan sebagainya sehingga semakin terbukanya pekerjaan yang lahir dari fenomena dari iklan. Hal ini disadari oleh pemerintah kota Mataram yang gencar mengizinkan berdirinya papan iklan yang disebut papan baliho di segenap penjuru kota. Saat ini Kota Mataram dari ujung barat sampai ujung timur dipenuhi oleh iklan.

Salah satu perusahaan yang ikut menebar promosinya melalui baliho di Kota Mataram adalah pemimpin pasar penyedia jasa layanan telekomunikasi seluler di Indonesia, yaitu Telkomsel yang menggunakan promosi dengan media iklan dengan pendekatan budaya etnis Sasak. Dalam iklan tersebut Telkomsel menampilkan sosok seorang pemusik tradisional Sasak sedang memainkan alat musik tradisional Sasak yang disebut dengan Gendang beleq, sambil melakukan komunikasi melalui telepon selulernya. Telkomsel melakukan hal tersebut mengingat etnis Sasak adalah mayoritas penduduk Kota Mataram dan Pulau Lombok.

\footnotetext{
*) Staf pengajar Jurusan Manajemen FE UNRAM

${ }^{* * *}$ Staf pengajar Univ. Muhammadiyah Mataram
} 
Selain Telkomsel, perusahaan telepon seluler lain yang turut menggunakan promosi dengan pendekatan budaya Sasak adalah XL. Dengan menggunakan bahasa Sasak, XL mencoba mengambil hasil masyarakat Sasak untuk menggunakan produk XL. Telkomsel dan XL menyadari untuk memenangkan kompetisi usaha maka dibutuhkan iklan yang handal terutama dalam menghubungkan perusahaan dengan masyarakat, khususnya para konsumen. Untuk itu mereka menggunakan iklan dengan pendekatan budaya Sasak yang menyentuh rasa kedaerahan pemirsanya. Apa yang dilakukan oleh Telkomsel dan XL ini sesuai dengan apa yang diterangkan oleh Johnson (2002) bahwa budaya termasuk lingkungan masyarakat, salah satu kekuatan lingkungan yang memaksa perusahaan pemasaran untuk mengikuti perubahan budaya dan nilai-nilai sosial, perilakuperilaku, tradisi-tradisi yang membentuk peradaban sebuah masyarakat.

Menurut Johnson (2002), pengaruh kuat dari kekuatan sosial dan budaya berada di pasar dunia. Perbedaan yang signifikan pada kepercayaan-kepercayaan agama, bahasa, status dan nilai-nilai keluarga, sikap terhadap pekerjaan dan hiburan, dan faktor-faktor lain yang mempengaruhi perilaku pembelian dan praktik-praktik pemasaran (Johnson, 2002). Sebagai contoh, McDonald's, KFC dan restauran-restauran cepat saji harus mengadaptasi budaya dan rasa lokal pada produk mereka. Di Indonesia misalnya, mereka harus menyertakan nasi sebagai ganti roti.

Bercermin dari deskripsi terkait dengan permasalahan iklan dan lingkungan budaya di atas dapat disarikan bahwa tantangan bagi Telkomsel adalah bukan sekedar meyakinkan konsumen dari masyarakat Sasak di Kota Mataram dengan iklan yang menggunakan pendekatan budaya. Tetapi lebih dari itu, tantangan untuk mewujudkan desain iklan dengan pendekatan budaya yang tepat bagi konsumennya, sehingga persepsi Telkomsel terhadap desain iklan dengan pendekatan budaya sama dengan apa yang dipersepsikan oleh konsumen dari Etnis Sasak. Tanpa penyamaan persepsi itu, penyedia jasa sering mengalami perbedaan persepsi dalam penyampaian iklan dengan konsumennya, sehingga timbul kesenjangan antara konsumen dengan penyedia jasa (Zeithaml dan Bitner, 2003). Untuk itu Telkomsel setidaknya perlu melakukan evaluasi terhadap desain iklan dengan pendekatan budaya yang ada saat ini serta mengetahui desain iklan dengan pendekatan budaya yang tepat berdasarkan kriteria evaluasi konsumen sebagai pembanding. Ini membuat peneliti merasa perlu dilakukan analisis tentang pengembangan desain iklan dengan pendekatan budaya milik Telkomsel. Dengan demikian, topik dalam penelitian ini adalah "Analisis Desain Iklan Dengan Pendekatan Budaya Menurut Kriteria Evaluasi Konsumen Di Kota Mataram (Studi Kasus Iklan Telkomsel Bernuansa Budaya Sasak)".

\section{KAJIAN TEORI}

Penelitian ini merupakan penelitian pemasaran terutama yang terkait dengan permasalahan pemasaran terutama promosi dan budaya konsumen. Karena itu peneliti mengkaji sejumlah teori yang terkait dengan komunikasi pemasaran, periklanan serta budaya konsumen dan perilakunya sehingga peneliti memiliki satu pandangan yang komprehensif terhadap fokus penelitian ini.

Bauran komunikasi pemasaran, menurut Kotler (2003) merupakan penggabungan dari lima model komunikasi dalam pemasaran, yaitu : 1) Iklan : Setiap bentuk presentasi yang bukan dilakukan orang dan promosi gagasan, barang, atau jasa oleh sponsor yang telah ditentukan; 2) Promosi Penjualan : Berbagai jenis insentif jangka pendek untuk mendorong orang mencoba atau membeli produk atau jasa; 3) Hubungan masyarakat dan pemberitaan : Berbagai program yang dirancang untuk mempromosikan atau melindungi citra perusahaan atau masing-masing produknya; 4) Penjualan pribadi : Interaksi tatap muka dengan satu atau beberapa calon pembeli dengan maksud 


\section{$J M M$ UNRAM \\ JURNAL MAGISTER MANAJEMEN UNIVERSITAS MATARAM

untuk melakukan presentasi, menjawab pertanyaan, dan memperoleh pemesanan; 5) Pemasaran langsung dan interaktif : Penggunaan surat, telepon, faksimili,e-mail, atau internet untuk berkomunikasi langsung atau meminta tanggapan atau berdialog dengan pelanggan tertentu dan calon pelanggan.

Kotler (2003), mengembangkan delapan langkah dalam program komunikasi dan promosi total yang efektif. Dimana komunikator pemasaran harus : (1) mengidentifikasikan audiensnya; (2) menentukan tujuan komunikasi; (3) merancang isi pesan; (4) memilih saluran komunikasi; (5) menentukan anggaran promosi; (6) membuat keputusan atas bauran pemasaran; (7) mengukur hasil promosi tersebut; dan (8) mengelola dan mengkoordinasi proses komunikasi pemasaran yang terintegrasi. Dari tahapan tersebut, diharapkan bahwa tanggapan terakhir dari audiens adalah berupa pembelian, kepuasan yang tinggi dan cerita dari mulut ke mulut yang baik.

Periklanan menurut Kotler (2003) didefinisikan sebagai segala bentuk penyajian non-personal dan promosi ide, barang, atau jasa oleh suatu sponsor tertentu yang memerlukan pembayaran.

Menurut Kotler (2003) upaya periklanan mempunyai beberapa tujuan antara lain: menginformasikan adanya merk produk di pasaran, membujuk konsumen untuk membeli produk, dan mengingatkan konsumen terhadap produk.

Iklan selain berfungsi memberitahu akan kehadiran suatu produk, juga memperlihatkan citra perusahaan kepada konsumen. Tanpa iklan, para konsumen yang berada jauh dari pusat-pusat produksi tidak akan memperoleh informasi mengenai barang yang dibutuhkannya. Iklan merupakan instrumen pemasaran modern yang aktifitasnya didasarkan pada pemikiran-pemikiran komunikasi (Engel, Blackwell dan Miniard, 1995).

Sebagai bagian dari komunikasi maka strategi kreatif akan semakin penting peranannya dalam upaya perusahaan membuat periklanan itu berhasil. Kotler dan Armstrong (2001) merumuskan tiga langkah strategi kreatif yang harus dikembangkan, yaitu : Pembangkitan Pesan, Evaluasi dan pemilihan pesan dan penyampaian pesan.

Johnson (2002) menyatakan masyarakat adalah salah satu kekuatan lingkungan yang memaksa perusahaan pemasaran untuk mengikuti perubahan budaya dan nilai-nilai sosial, perilaku-perilaku, dan tradisi-tradisi yang membentuk peradaban sebuah masyarakat. Faktor-faktor ini mempengaruhi pemasaran dengan tiga cara penting. Pertama, trend sosial dan budaya menghasilkan pengenalan produk baru dan praktik pemasaran baru. Pada masa ini di Indonesia dan di seluruh dunia, tekanan waktu dan jarak dari orang tercinta menjadi isu penting bagi masyarakat. Untuk itu internet, laptop dan telepon seluler saat ini disediakan oleh perusahaan pemasaran sehingga orang dapat tetap berhubungan dengan orang tercintanya dan bahkan rekan kerjanya dimanapun ia berada.

Kedua, produk baru dan aktivitas-aktivitas pemasaran yang lain memiliki pengaruh pada tren sosial dan budaya. Produk hasil inovasi baru seperti sebuah kamera digital dan televisi satelit memiliki dampak yang besar pada hidup kita. Seperti bagaimana pentingnya telepon selular bagi remaja-remaja yang aktif dalam kehidupan sosial. Iklan dan tehnik-tehnik promosi yang lain juga turut mempengaruhi perilaku dan nilai-nilai yang ada dalam masyarakat kita (Johnson, 2002).

Ketiga, hambatan pada aktivitas-aktivitas dan praktik-praktik pemasaran sebagaian besar berasal dari lingkungan masyarakat. Rokok terbatas untuk konsumen tertentu. Iklan rokok di radio dan televisi dibatasi di waktu tertentu, seperti di bungkus rokok. Bahkan di beberapa tempat kegiatan merokok dibatasi hanya di area pribadi (Johnson, 2002).

Arnould dan Thompson (2005) menyatakan bahwa "Consumer Culture Theory is a marketing school of thought interested in studying consumption choices and behaviours from a social and cultural point of view, as opposed to an economical or psychological one. It does not offer a grand unifying theory but "refer to a family of 


\section{$J M M$

theoretical perspectives that address the dynamic relationships between consumer actions, the marketplace, and cultural meanings". Selanjutnya Arnould (2006) menambahkan bahwa "Consumer culture is viewed as

"social arrangement in which the relations between lived culture and social resources, between meaningful ways of life and the symbolic and material resources on which they depend, are mediated through markets".

Dari kedua pengertian di atas dapat disimpulkan bahwa teori budaya konsumen adalah pemikiran para ahli pemasaran yang merupakan abstraksi dari kondisi empiris konsumen yang dilihat dari kondisi sosial dan budaya yang berhubungan dengan perilaku konsumen. Chaharsoughi dan Yasory (2011) menyatakan bahwa adaptasi budaya merupakan hal yang penting dalam melakukan promosi. Pendapat Chaharsoughi dan Yasory (2011) didukung oleh Luna and Gupta, (2001); Ogden and Schau, (2004) yang menyatakan bahwa budaya memiliki efek yang nyata pada perilaku seseorang. Dengan pemahaman terhadap budaya maka sebuah perusahaan dapat melakukan promosi yang menyentuh individu yang memiliki budaya tertentu. Luna dan Gupta (2001) seperti yang dikutip dari Chaharsoughi dan Yasory (2011) dalam modelnya menyatakan, budaya adalah suatu yang terlihat melalui nilai-nilai, kepahlawanan, ritual-ritual dan symbol-simbol. Nilai adalah inti dari budaya dan nilai mempengaruhi perilaku konsumen. Sementara komunikasi pemasaran bertindak selaku moderator dari dampak budaya pada perilaku konsumen dan berdampak pada perilaku konsumen secara mandiri pada budaya.

Chaharsoughi dan Yasory (2011) menyatakan bahwa baik promosi dan budaya memiliki pengaruh pada perilaku konsumen, di sisi lain perilaku konsumen memiliki pengaruh terhadap budaya dan promosi. Dari pendapat Chaharsoughi dan Yasory (2011) dan pendapat Luna dan Gupta (2001) dalam Chaharsoughi dan Yasory (2011 tadi dapat diketahui bahwa Komunikasi pemasaran termasuk iklan di dalamnya membutuhkan pengetahuan tentang budaya.

Dalam kegiatan pemasaran, pemasar adalah seseorang yang mencari tanggapan (perhatian, pembelian, pemberian suara, sumbangan) dari pihak lain, yang disebut calon pelanggan (prospect) (Kotler dan Keller, 2006). Menurut Mulyadi (2001:224) dalam Rinuastuti dan Rusdan (2008), Customer adalah siapa saja yang menggunakan keluaran pekerjaan seseorang atau suatu tim, mencakup pengertian pelanggan (repeat buyer), pembeli sekali (one-time buyer), maupun konsumen (consumer). Pemasar harus berupaya untuk memahami kebutuhan, keinginan, dan permintaan pasar sasaran. Perusahaan memenuhi kebutuhan dengan mengajukan usulan/ proposisi nilai, yaitu serangkaian manfaat yang ditawarkan kepada para pelanggan guna memuaskan kebutuhan mereka (Kotler dan Keller, 2006). Proposisi nilai yang tak berwujud (intangible) dibuat menjadi sesuatu yang bersifat fisik yang berupa tawaran (offering), yang dapat berupa gabungan produk, jasa, informasi, dan pengalaman.

\section{METODE PENELITIAN}

Karena penelitian ini akan mengumpulkan berbagai bukti empiris terkait dengan kriteria desain iklan dengan pendekatan budaya yang sesuai dengan evaluasi konsumen masyarakat Etnis Sasak di Kota Mataram, melakukan observasi, wawancara dan interaksi dengan partisipan sehingga didapat nantinya desain iklan dengan pendekatan budaya yang sesuai dengan evaluasi konsumen yang berasal dari masyarakat Sasak di Kota Mataram, maka penelitian ini dapat dikategorikan sebagai penelitian diskriptif kualitatif (Creswell (2006).

Populasi dari penelitian ini adalah penduduk Kota Mataram dari Suku Sasak. Jumlah penduduk di Mataram yang tercatat sampai dengan akhir tahun 2009 adalah 362.243 orang (http:/ /ntb.bps.go.id/, 2012). Sekitar 80 persen (289.795 orang) penduduk kota ini adalah suku Sasak, (http://id.wikipedia.org /wiki/ Kota_Mataram, 2012). Menurut Cooper dan Schindler (2001) apabila 
jumlah populasi dan jumlah sampel diketahui maka peneliti harus menggunakan metode non probability sampling, karena itu penelitian ini menggunakan metode non probability sampling yaitu metode purposive random sampling. Sampel dalam penelitian ini adalah Penduduk Kota Mataram yang berasal dari Suku Sasak.

Untuk Tahapan Studi Awal lapangan yang terdiri dari Observasi Partisipatif, Focus Group dan Wawancara mendalam ditetapkan jumlah sampel sebanyak 30 orang. Ini didasarkan pada pendapat Roscoe dalam Wibisono (2000) yang mengatakan bahwa ukuran sampel untuk setiap penelitian harus berada antara 30 dan 500. Untuk Tahapan Survei, penentuan jumlah sampel dilakukan dengan menggunakan rumus Slovin sebagai berikut $\mathrm{n}=\mathrm{N} /\left(1+\mathrm{Ne}^{\wedge} 2\right)$ dengan Total populasi 289795 dan Toleransi kesalahan (Error tolerance) 0,10, maka didapat $\mathrm{n}=99,965505$ yang dibulatkan menjadi $\mathrm{n}=100$.

Penelitian ini menggunakan beberapa cara untuk mengumpulkan data yaitu Metode Observasi partisipatif, Studi dokumentasi, Wawancara, Focus group discussion (FGD), dan Survei (sample survey).

\section{HASIL DAN PEMBAHASAN}

\subsection{Hasil Penelitian Pendahuluan}

Pada tahap awal peneliti melakukan kajian dengan melakukan penelitian kualitatif dengan beberapa metode yaitu Kajian Dokumen, Wawancara dan focus group discussion, untuk mengkaji apa saja yang didapatkan dari hasil kajian tersebut berkaitan dengan Desain Iklan Dengan Pendekatan Budaya Menurut Kriteria Evaluasi Konsumen Di Kota Mataram . Berikut ini hasil kajian yang dilakukan peneliti.

\subsubsection{Gambaran Kondisi Lapangan}

Lokasi penelitian dipilih di Kota Mataram, Ibukota Propinsi Nusa Tenggara Barat ini dikenal dengan letaknya sangat strategis dan menjadi pusat berbagai aktifitas seperti pusat pemerintahan, pendidikan, perdagangan, industri dan jasa, saat ini sedang dikembangkan untuk menjadi kota pariwisata.

Kota Mataram terletak di bagian barat Pulau Lombok. Sebelah utara, timur, dan selatan berbatasan dengan Kabupaten Lombok Barat, sedangkan sebelah barat berbatasan dengan Selat Lombok. Secara astronomis berada pada posisi $8^{\circ} 33^{\prime}-8^{\circ} 38^{\prime}$ LS dan $116^{\circ} 04^{\prime}-116^{\circ} 10^{\prime}$ BT. Luas wilayah Kota Mataram mencapai 61,3 km², terbagi dalam 6 kecamatan, yaitu: Ampenan, Mataram, Cakranegara, Sekabela, Selaparang dan Sandubaya. Jumlah penduduk Kota Mataram 353.183 jiwa pada tahun 2006. Mataram memiliki luas wilayah 61,30 km2 (Pramono, 2008). Penduduk etnis Sasak Islam di Mataram \pm 225.000 jiwa dan \pm 25.000 jiwa penduduk suku lain yang beragama Islam.

Kota Mataram dihuni oleh mayoritas suku bangsa Sasak (70 persen). Selebihnya penduduk kota Mataram terdiri dari etnik Bali (15 persen), Tionghoa, Arab, Melayu, Banjar, Bugis, Jawa, Sumbawa, Bima, Timor, Ambon dan etnik-etnik lain dalam jumlah kecil.

Kota Mataram merupakan kota terkaya di Nusa Tenggara Barat dengan rata-rata pendapatan per kapita sebesar Rp3.822.161 dan rata-rata pertumbuhan ekonomi 7,93 persen. Sebagai pusat pemerintahan dan pusat kegiatan perekonomian, Kota Mataram memiliki keunggulan di sektor industri pengolahan, sektor listrik, gas dan air bersih, sektor pengangkutan dan komunikasi serta sektor keuangan, persewaan dan jasa perusahaan. Perekonomian di Kota Mataram hingga akhir 2006 telah berkembang pesat dibandingkan kondisi pada tahun 2001, saat itu Kota Mataram tergolong daerah maju tapi tertekan (bi.go.id, 2011). 
Salah satu operator seluler di Mataram adalah Telkomsel. Perusahaan ini operator telekomunikasi seluler GSM pertama di Indonesia dengan layanan pascabayar kartuHALO yang diluncurkan pada tanggal 26 Mei 1995. Saat itu, saham Telkomsel dimiliki oleh Telkom Indonesia sebesar 65 persen dan sisanya oleh Indosat. Pada tanggal 1 November 1997, Telkomsel menjadi operator seluler pertama di Asia yang menawarkan layanan GSM prabayar.

Telkomsel memiliki tiga produk GSM, yaitu simPATI (prabayar), Kartu AS (prabayar), dan kartuHALO (pascabayar). Selain itu, Telkomsel juga memiliki layanan internet nirkabel lewat jaringan telepon seluler, yaitu Telkomsel Flash. Kartu As adalah layanan seluler pra bayar (pre-paid) dari Telkomsel dengan tarif yang kompetitif didukung oleh jaringan terluas, dan pasar sasaran peer group atau teman dan keluarga. Head of Telkomsel Branch Mataram, Erwien Kusumawan, mengungkapkan, hingga bulan Agustus 2012, pelanggan kartu AS bergambar kesenian Presean meningkat 200 persen di Lombok. Angka itu mengalami peningkatan 3 kali lipat dibandingkan jumlah awal tahun 2012 lalu. Seluruh target penjualan dan penambahan jumlah pelanggan yang seharusnya dicapai akhir tahun 2012, ternyata sudah terpenuhi pada bulan Juli 2012. Produk ini sangat cocok untuk memenuhi kebutuhan komunikasi sehari-hari (http://globalfmlombok.com, 2012).

"Kondisi ini menunjukkan bahwa masyarakat di NTB, khususnya pulau Lombok sudah mulai paham tentang produk Telkomsel, yakni kartu AS yang murah dan berkualitas. Kartu AS Lombok ini memang kami persembahkan untuk masyarakat Lombok," kata Erwien Kusumawan, ditemani Head of Network Service Nusa Tenggara, Eddy Putra dan Coporate Communications Telkomsel Bali Nusra, Pandu Maulana, kepada wartawan di kantor GRApari Mataram, Senin (1/10) (http://globalfmlombok.com, 2012).

Erwien menuturkan, peningkatan jumlah pelanggan kartu AS ternyata berbanding lurus terhadap peningkatan pendapatan di Lombok. Di mana, pada periode Januari hingga Agustus 2012, pendapatan Telkomsel dari Kartu AS meningkat lebih dari 140 persen dibanding pada awal tahun ini. Traffic layanan suara dan SMS juga mengalami peningkatan sekitar 200 persen dalam 8 bulan terakhir. Kini tingkat utilisasi layanan Telkomsel di Lombok mencapai 70 persen (http:/ / globalfmlombok.com, 2012).

Head of Network Service Nusa Tenggara, Eddy Putra, menambahkan, seiring penambahan jumlah pelanggan dan jumlah pendapatan, Telkomsel telah membangun tambahan sekitar 130 BTS di pulau Lombok. "BTS yang paling banyak diadakan di Kabupaten Lombok Timur (Lotim), karena transaksi voice dan data di sana tertinggi di pulau Lombok. Ini semua untuk meningkatkan layanan seara berkala agar masyarakat Lombok bisa menikmati murahnya tariff SMS, telpon dan data dengan kartu AS Lombok," tambahnya (http:/ / globalfmlombok.com, 2012).

\subsubsection{Deskripsi Demografi Partisipan}

Untuk mendapatkan gambaran tentang partisipan, pada metode kualitatif digunakan kuesioner pembantu wawancara dan Focus Group Discussion, sedangkan pada survei, para partispan diminta mengisi lembar indentitas partisipan. Para partisipan penelitian ini seluruhnya berjumlah 100 orang. Partisipan-partisipan yang berpartisipasi untuk kegiatan wawancara berjumlah 10 orang. Total partisipan yang terlibat dalam Focus Group Discussion berjumlah 90 orang. Berikut ini gambaran demografi partisipan penelitian ini.

Ciri-ciri demografi partsipan adalah jenis kelamin pria, dengan status menikah, usia 2630 tahun dengan tingkat pendidikan sarjana, status pekerjaan lain-lain, pengeluarannya di atas satu juta rupiah, telah melakukan pembelian kartu provider telpon seluler sebanyak dua kali, membeli produk kartu 
provider telepon seluler karena didorong oleh keinginan diri sendiri, mengetahui produk provider jasa seluler dari televisi, berpenghasilan di atas Rp.2.000.000 dalam sebulan, pernah menggunakan 2 merek provider jasa seluler, membeli kartu provider telepon seluler pada toko.

\subsubsection{Hasil Wawancara}

Untuk mengetahui fenomena Iklan Dengan Pendekatan Budaya di Kota Mataram maka peneliti melakukan wawancara terhadap sejumlah anggota masyarakat Sasak di Kota Mataram. Peneliti mewawancarai 10 orang partisipan. Dari pernyataan partisipan tadi dapat dikelompokkan ke dalam tujuh tema yang signifikan terkait dengan fokus penelitian sebagai berikut ini:

TEMA BUDAYA DAN EDUKASI KONSUMEN: Desain iklan dengan pendekatan budaya menjadi salah satu daya tarik iklan Kartu As. Ini diakui oleh seorang partisipan, wanita, berusia 24 tahun sebagai berikut : "Saya selaku suku Sasak bangga karena diangkatnya budaya Sasak yaitu peresean dan gendang beleq sebagai sampul dan iklan kartu Telkomsel, setidaknya ini akan membuat orang tertarik untuk mendalami budaya Sasak dan membeli Kartu As.". Partisipan lain menambahkan "Desain iklan ini Menarik. Ini adalah salah satu cara untuk mengeksplorasi budaya Indonesia, terutama budaya Sasak, bagaimana pemahaman budaya sangat perlu bagi masyarakat".

TEMA GAMBAR: Bagi kebanyakan masyarakat Etnis Sasak di Mataram, gambar iklan sangat penting. Ini tercermin dari hasil wawancara dengan seorang wanita di Dasan Agung yang mengatakan: "Setelah saya melihat gambar iklan Telkomsel, saya tertarik dengan gambar tersebut, karena gambar tersebut memperlihatkan adat dan istiadat suku Sasak dengan kesenian Gendang beleq $"$.

TEMA DESAIN DAN SLOGAN: Dari sejumlah partisipan dari berbagai kalangan Etnis Sasak di Kota Mataram yang berhasil diwawancara diketahui banyak yang menyukai Iklan Telkomsel AS karena desain dan slogannya. Seorang partisipan berusia 21 tahun mengatakan: "Desain iklan Telkomsel tersebut sangat Menarik, ada budaya Sasak dan ada Slogan yang menyakinkan. Slogan ini berarti memberikan harapan bahwa kartu tersebut cocok untuk orang Lombok".

TEMA INFORMASI HARGA: Dari 10 orang partisipan yang diwawancarai tentang informasi harga, diketahui bahwa masyarakat Sasak di Kota Mataram menganggap tampilan informasi dalam iklan Kartu As sangat penting. Misalnya seorang partisipan wanita di daerah Ampenan Mataram, yang menyatakan "Kartu As yang dikeluarkan Telkomsel dikhususkan untuk daerah Lombok, harga murah cuman 2000 ". Seorang partisipan lain yang juga bertempat tinggal di Ampenan, mengemukakan "Dari segi harga, iklan ini memberikan informasi bahwa harga kartunya cukup terjangkau, namun tariff SMS, telepon dan internetnya cukup mahal"

TEMA CITRA: Sejumlah partisipan dari suku Sasak merasa iklan yang menampilkan gendang beleq akan memberikan citra yang lebih baik dibanding dengan apa bila Kartu As menampilkan peresean. Salah seorang warga Sasak menganggap citra itu penting bagi dirinya sebagai orang Sasak. Iklan dari perusahaan menurutnya harus menampilkan pencitraan positif bagi perusahaan dan suku bangsa yang budayanya diambil sebagai bagian dari iklan. Partisipan itu menyatakan "saya kurang setuju dengan gambar peresean, ini cenderung melambangkan kekerasan, saya takutnya orang menganggap orang Sasak itu keras, mungkin lebih baik diambil contoh budaya Sasak yang lain seperti Gendang beleq" Pendapat partisipan tadi disetujui oleh partisipan lainnya sebagai berikut: "dari segi gambar, kalau pakai gendang beleng akan lebih baik karena peresean akan memperlihatkan pribadi orang yang suka berkelahi, itu tidak sesuai dengan citra orang Lombok yang shaleh". Sebagian besar anggota masyarakat Sasak merasa keluarga, agama, komunitas dan negara penting bagi mereka. 
TEMA WARNA DAN DESAIN: Sebagian dari anggota masyarakat Sasak di Kota Mataram yang berhasil ditemui cenderung kurang menyukai warna sampul kartu As bergambar Peresesan namu mereka suka dengan warna dari iklan bergambar gendang beleq dari iklan Telkomsel. Seperti yang dikatakan oleh partisipan berikut ini. "saya melihat warna sampul kartu As tersebut terlihat pucat dan kurang menarik kalo iklannya saya suka". Partisipan lain menyatakan bahwa "desain sampul kartu As yang digunakan tidak menarik Karena warna yang digunakan tidak sesuai dengan brank yang lebih condong menggunakan warna merah dan putih. Sebaiknya sampul ini mengikuti iklannya"

TEMA INFORMASI FITUR DAN FASILITAS: Sebagian besar masyarakat Sasak di Kota Mataram menganggap dipandang perlu sebuah iklan penyedia jasa telepon seluler memperlihatkan fasilitas dan fitur. Ini dapat disimak dari wawancara dengan partisipan-partisipan berikut ini "menurut pendapat saya iklan ini kurang Menarik, karena tidak adanya gambar atau penjelasan tentang jejaring social dalam iklan tersebut dan banyak hal yang membuat kebingungan". Dengan demikian dapat dikatakan bahwa di masyarakat Sasak yang ada di Kota Mataram terdapat sejumlah segmen pendapat tentang iklan Telkomsel Kartu As. Selanjutnya harus ditemukan Desain Iklan yang sesuai dengan persepsi konsumen yaitu dengan melakukan penelitian tentang Iklan Dengan Pendekatan Budaya. Untuk itu penelitian ini dapat dilanjutkan dengan Focus Group Research, dengan tujuan untuk memperdalam pengetahuan tentang iklan Telkomsel Kartu As di Mataram.

\subsubsection{Hasil Focus Group Research}

Tujuan FGD ini adalah mengetahui pendapat dan pengalaman dari masing-masing individu yang termasuk dalam kelompok masyarakat tentang persepsi mereka mengenai desain iklan bernuansa budaya Sasak. Focus Group Discussion (FGD) ini dilakukan pada tanggal 2, 3, dan 6 November 2012, masing-masing dilakukan 2 sesi (kelompok) diskusi, sehingga total ada 6 FGD yang dilaksanakan. Tiap FGD diikuti oleh 5 orang warga Etnis Sasak di Kota Mataram.

\subsubsection{Temuan Umum FGD}

Dari FGD pertama dapat diketahui bahwa Desain iklan Telkomsel dengan budaya Sasak cukup Menarik, namun perlu banyak variasi, sehingga tidak hanya gendang beleq dan peresean saja. Untuk memposisikan produk merek Kartu As sebagai kartunya orang Lombok, Telkomsel sebaiknya menggunakan tidak hanya gambar budaya tapi juga tempat wisata dan keindahan alam di Lombok. Promosi menerangkan Kartu As memiliki jaringan yang luas, sehingga perlu ditambah kemampuan pemancar Telkomsel hingga ke pelosok Lombok.

Dari FGD kedua dapat diketahui bahwa Iklan Telkomsel ini dirasa sudah mampu memberikan citra produk di benak konsumennya. Iklan dengan pendekatan budaya akan lebih mudah mendapatkan persepsi positif dari masyarakat pemilik budaya tersebut. Untuk mengangkat budaya Sasak, sebaiknya lebih banyak lagi variasinya karena bukan hanya gendang beleq dan peresean saja yang ada di budaya itu.

Dari FGD ketiga dapat diketahui bahwa Iklan tersebut Menarik karena menampilkan identitas budaya Sasak. Tujuan dari iklan ini searah dengan slogannya “Kartunya Orang Lombok@. Positioning produk ini sudah sangat jelas sekali.

Dari FGD ke empat dapat diketahui bahwa Iklan ini memiliki nilai positif yaitu : memperkenalkan budaya Sasak dan Telkomsel terutama paket program dan kualitas sinyal Kartu As. Di sisi lain iklan ini harus menampilkan variasi budaya Sasak seperti Baju adat Sasak dan Adat Sasak seperti nyongkol. Untuk gambar, kondisi alam Lombok yang indah bisa menjadi pilihan, seperti gambar Gili 


\section{$J M M$

Trawangan, Gili Air, Gunung Rinjani dan sebagainya. Iklan akan diperhatikan kalau berada di tempat yang sering dilihat konsumen. Semakin besar iklan semakin baik.

Dari FGD ke lima dapat diketahui bahwa Telkomsel sudah menampilkan budaya Sasak yang member kesan positif, namun sayangnya sedikit tidak masuk akal karena orang yang sedang menambuh gendang beleq sambil menggunakan telepon selulernya. Penjelasan mengenai fitur dan fasilitas produk masih kurang. Harga layanan kurang jelas. Untuk Telkomsel sebaiknya konsisten antara promo dan praktik layanannya.

Dari FGD ke enam diketahui bahwa Sebaiknya Telkomsel menampilkan budaya Sasak yang original, tanpa melakukan perubahan, seperti yang dilakukan pada penggambaran gendang beleq, pada iklan terlihat penabuh gendang beleq menabuh sambil berkomunikasi dengan handphone. Penjelasan tentang harga sangat perlu mengingat konsumen di Lombok punya banyak pilihan dan dengan harga yang cukup murah. Penjelasan tentang saluran distribusi penting, mengingat Kartu As termasuk baru bila dibanding Simpati dan XL. Perlu penjelasan tentang produk lain selain telpon dan SMS.

\subsubsection{Hasil Workshop}

Selanjutnya pada tanggal 9 November 2012 dilakukan Workshop untuk menyatukan hasil penerapan metode penelitian dan memetakan persepsi masyarakat Sasak. Hasil workshop yang dilakukan oleh Tim penelitian bersama para pihak berkepentingan sebagai berikut. Pertama, hal yang terpenting yang perlu diperhatikan oleh Telkomsel dalam membuat iklan bernuansa adat Sasak adalah originalitas dari adat tersebut. Kedua, ditemukan juga sejumlah atribut yang nantinya mempengaruhi daya tarik iklan Kartu As bernuasa budaya Sasak yaitu:

- Warna dan Gambar menentukan dalam sebuah iklan berlatar budaya,

- Informasi fitur dan fasilitas yang modern dan menyesuaikan dengan kepentingan konsumen yang terus bertambah seiring perkembangan teknologi menjadi salah satu atribut penting yang ada dalam iklan.

- Slogan hendaknya menyesuaikan dengan pasar sasaran yang dituju.

- Informasi Harga menjadi penting karena konsumen peka terhadap harga.

- Ukuran, semakin besar semakin baik untuk menarik perhatian konsumen.

- Sebaiknya menggunakan berbagai macam Media Iklan tidak hanya papan iklan saja.

- Lokasi Iklan menjadi penting bagi Telkomsel, mengingat konsentrasi pemirsa iklan tidak hanya di jalan atau di tempat-tempat strategis tetapi juga di kampung-kampung.

\subsection{Pembahasan}

Dari tujuan penelitian ini ada dua hal yang ingin digali dari seluruh kegiatan prosedur penelitian. Pertama, untuk mengetahui desain iklan dengan pendekatan budaya menurut kriteria evaluasi konsumen dari Etnis Sasak di Kota Mataram berdasarkan hasil dari prosedur penelitian kualitatif dan penelitian kuantitatif. Kedua, diketahuinya desain iklan dengan pendekatan budaya menurut kriteria evaluasi konsumen petunjuk untuk menyelesaikan persoalan bisnis di Kota ini dari segi pembuatan iklan yang tepat sesuai dengan kriteria evaluasi konsumen.

Untuk menjawab permasalahan penelitian tersebut dalam penelitian ini digunakan dua metode yaitu metode kualitatif dan metode kuantitatif. Dari hasil penelitian pendahuluan, desain iklan seluler Kartu As di Kota Mataram yang dihendaki konsumennya mulai dapat direka. Dari penelitian pendahuluan dengan metode kualitatif didapatkan delapan atribut iklan Kartu As bernuasa budaya 


\section{$J M M$

Sasak yang penting di benak penduduk Kota Mataram yaitu . 1) Warna, 2) Gambar ,3) Informasi fitur dan fasilitas, 4) Slogan, 5) Informasi Harga, 6) Ukuran, 7) Media Iklan, dan 8) Lokasi Iklan.

Salah satu atribut yang ditemukan dalam penelitian kualitatif adalah warna dalam dalam desain iklan Kartu As. "Warna berkomunikasi" begitu kata para ahli. Hal ini dapat memberikan arahan dan kejelasan. Saat bahasa gagal warna dapat menawarkan asosiasi berharga dengan orang, tempat dan hal-hal. Tentara hijau. Api mesin merah. Tengah malam hitam. Langit biru. Tindakan hanya membaca warna-warna membangkitkan perasaan yang berbeda. Warna menginduksi emosi halus, dan memunculkan tanggapan yang kuat. Karena dampaknya adalah warna begitu mendalam, itu peran dalam desain dan branding adalah kritis dan dapat mencapai hasil yang luar biasa (http://id.prmob.net, 2012).

Keith (1970) dalam Engel dkk (1995) menyatakan bahwa salah satu upaya untuk meningkatkan kekuatan pemikat dan penahan perhatian dari stimulus pemasaran adalah dengan penggunaan warna. Dicontohkan oleh Percy (1984) dalam Engel dkk (1995) bagaimana perbandingan antara penjualan satu produk yang mempromosikan dengan warna kuning dan merah yang mendorong perusahaan yang tadinya beriklan di halaman kuning pindah ke halaman merah. Percy (1984) dalam Engel dkk (1995) juga mencontohkan iklan surat kabar yang berwarna menghasilkan 41 persen penjualan lebih banyak dibanding iklan hitam putih. Dengan demikian bisa dikatakan bahwa Warna menjadi unsur penting dalam suatu iklan.

Atribut iklan terpenting ke dua menurut hasil penerapan metode kualitatif adalah Gambar. Menurut Engel dkk (1995), Gambar merupakan saah satu unsur stimulus yang dapat dipergunakan oleh pemasar dalam iklan. Engel dkk (1995) menyatakan bahwa konsumen dapat dimotivasi melalui gambar dan tampilan dalam iklan lainnya. Dari gambar iklan konsumen dimotivasi oleh faktor rasional dan emosional. Dalam kasus iklan Kartu As Telkomsel yang bergambar penabuh gendang beleq menggunakan handphone, pasar sasaran yaitu orang Lombok dimotivasi dengan faktor emosional kedaerahan. Rasa cinta akan budayanya akan merangsang suku Sasak untuk membeli kartu perdana dari Telkomsel ini.

Atribut terpenting ke tiga adalah Informasi fitur dan fasilitas. Ini merupakan bagian dari bauran produk yang melekat pada produk Kartu As Telkomsel. Menurut Kotler (2000), bauran pemasaran yang paling dekat dengan produksi dan pelayanan adalah bauran produk. Fitur, fasilitas, citra, kemasaran dan merek merupakan bagian yang tidak terlepaskan dari satu produk. Salah satu Tujuan promosi adalah Menyebarkan informasi produk kepada target pasar potensial. Dengan memberikan informasi fitur dan fasilitas maka konsumen akan percaya pada kemampuan produk yang akan dia beli.

Atribut iklan Telkomsel AS yang berhasil mengemukan dari penelitian ini adalah Slogan. Ini jarang yang membentuk kalimat. Kata-kata Slogan iklan yang paling mengena tak bisa menjadi sebuah kalimat. Namun lebih banyak didasarkan pada pengemasan bahasa agar enak didengar, atau mengikuti arus trend berbahasa yang tengah muncul (Trimarsanto, 2008 dalam Lungkang, 2008.). Atribut ini menjadi salah satu daya tarik iklan. Dalam kasus iklan Telkomsel AS yang sekarang melakukan repositioning dan diversifikasi produknya, dengan melakukan pemasaran berdasar daerah dan paket. Salah satu produk hasil diversifikasi daerah adalah Kartu As Lombok, dengan pasar sasaran warga Pulau Lombok. Kartu perdana As Lombok bertulis slogan "Kartunya Orang Lombok".

Informasi Harga merupakan atribut ke enam terpenting menurut persepsi partisipan penelitian ini. Bauran pemasaran Harga adalah satu-satunya bauran pemasaran yang mendatangkan pendapatan (Kotler, 2000). Dalam kasus Kartu As Lombok 
Ukuran, merupakan atribut ke enam terpenting menurut persepsi partisipan penelitian ini. Menurut Engel dkk (1995) pada umumnya semakin besar ukuran stimulus, maka semakin stimulus itu menarik perhatian. Finn (1988) dalam Engel dkk (1995) menyatakan bahwa menambah ukuran cetak iklan akan meningkatkankan kemungkinan mendapatkan perhatian dari konsumen. Ukuran, Media Iklan dan Lokasi Iklan merupakan tiga hal yang berkaitan satu dengan lainnya. Media Iklan berupa papan iklan yang besar dan terletak di lokasi yang padat penduduk memudahkan calon konsumen untuk mengamati dan selanjutnya tertarik terhadap iklan. Atribut itu selanjutya didalami dengan penelitian metode kuantitatif.

Dalam penelitian ini, Metode Kuantitatif yang digunakan adalah prosedur analisis conjoint. Alat analisis ini adalah sebuah method kuantitatif yang digambarkan oleh Steekamp (1987) dalam Bogue et al (2005) sebagai metode yang berorientasi pada konsumen yang mengkuantitatifkan dan memprediksi penilaian konsumen secara keseluruhan terhadap satu produk dengan basis atribut inti produk tersebut. Green dan Srinivasan (1978) dalam Bogue et al (2005) menyatakan bahwa analisis conjoint menyediakan informasi untuk peneliti tentang struktur preferensi konsumen, yang didapat dari penilaian konsumen secara keseluruhan terhadap satu alternatif kombinasi level/tingkatan dari atribut-atribut yang berbeda-beda. Lebih lanjut, Green dan Krieger (1991) dalam Bogue et al (2005) menjelaskan bahwa penggunaan potensial dari alat analisis conjoint adalah untuk pengembangan produk-produk multi atribut baru dengan tingkat utilitas optimal, untuk mengestimasi pangsa pasa di berbagai alternatif scenario kompetisi, dan untuk membuat segmentasi pasar dan stategi promosi. Menurut Steenkamp (1987) dalam Bogue et al (2005) ada dua asumsi dasar yang mendukung analisis conjoint. Asumsi pertama adalah produk dapat digambarkan sebagai kombinasi tingkatan atau level dari sebuah kumpulan atribut, dan asumsi kedua adalah level-level tadi menentukan penilaian konsumen secara keseluruhan terhadap sebuah produk. Selanjutnya dengan memadukan hubungan tersebut didapatkan satu desain produk (barang maupun jasa) yang sesuai dengan preferensi konsumen.

Metode dalam analisis conjoint ini adalah dengan mengestimasi part - worth untuk tiap faktor. Makin besar part - worth, maka makin besar pula dampaknya terhadap utilitas keseluruhan. Estimasi part - worth Iklan Kartu As dengan kombinasi 1) Warna Mengikuti Warna Khas Perusahan; 2) Gambar Kesenian Dan Kegiatan Budaya Sasak Lainnya; 3) Informasi Fitur Dan Fasilitas Fitur Utama Dan Tambahannya; 4) Slogan Terkait Dengan Identitas Pulau Lombok; 5) Informasi Harga Jelas Di Setiap Fitur Yang Dipromosikan; 6) Ukuran Extra Besar; 7) Media Iklan Papan Iklan/Baliho Atau Spanduk Dan 8) Lokasi Iklan Di Setiap Tempat Padat Penduduk menghasilkan total utilitas tertinggi di antara 16 kombinasi, dengan nilai Total Utilitas sebesar 8,135. Dengan demikian dapat dikatakan bahwa kombinasi ini adalah kombinasi desain iklan seluler Kartu As di Kota Mataram yang paling ideal menurut responden.

Prosedur analisis conjoint selanjutnya adalah estimasi nilai tingkat kepentingan relatif. Perhitungan ini memperlihatkan bahwa faktor yang terpenting menurut penilaian responden adalah Gambar dengan nilai kepentingan 18,451 .

Untuk lebih menyakinkan pembentukan desain maka prosedur analisis conjoint melakukan estimasi regresi linier. Dari regresi linier ini diketahui bahwa lima faktor memiliki kontribusi positif terhadap peningkatan utilitas Warna dengan kontribusi sebesar 3,77 persen; Gambar 10,33 persen; Informasi fitur dan fasilitas 3,05 persen; Slogan 1,09 persen dan Informasi Harga 5,05 persen. Di sisi lain ada tiga faktor yang kontribusinya negatif terhadap utilitas Ukuran; Media Iklan; Lokasi Iklan. Gambar menjadi kontributor terbesar pada utilitas karena apabila Gambar meningkat satu satuan maka utilitas meningkat sebesar 10,33 persen. Ini mengkonfirmasi hasil dari prosedur conjoint sebelumnya yaitu estimasi nilai tingkat kepentingan relatif. 
Hasil yang diperlihatkan oleh dua prosedur analisis conjoint yaitu estimasi nilai tingkat kepentingan relatif dan estimasi regresi linier menunjukkan bahwa Gambar menjadi faktor terpenting dan memiliki kontribusi terbesar terhadap utilitas konsumen.

Dari hasil kombinasi desain iklan seluler Kartu As di Kota Mataram yang paling ideal didapatkan informasi terkait mengenai apa yang harus dilakukan oleh Telkomsel dalam mengembangkan iklan bernuansa budaya Sasak. Sebagai dampaknya, pemasaran dari Kartu As Telkomsel secara proaktif menyiapkan berbagai hal yang terkait dengan iklan bernuansa budaya yang ideal menurut penilaian konsumen itu, misalnya dengan menyiapkan pendukung untuk atribut-atribut iklan bernuansa budaya dan konsep implementasi yang tepat. Paling tidak Telkomsel harus menyediakan Gambar yang tepat untuk mendukung iklan bernuansa budaya Kartu As ini.

Gambar yang harus disiapkan oleh Telkomsel untuk iklan bernuansa budaya ini adalah gambar yang berhubungan dengan kesenian dan kegiatan Budaya Sasak lainnya. Maksudnya di sini adalah bagaimana ada gambar budaya Sasak yang lebih bervariasi tidak hanya gendang beleq dan perisaian. Selain itu atribut-atribut iklan lainnya harus disiapkan dengan cermat.

Atribut lain yang mendukung adalah warna, informasi harga, informasi fitur produk dan slogan. Dari hasil penelitian ini disarankan untuk menggunakan warna khas perusahaan. Ini masuk akal karena bagi konsumen citra perusahaan yang ditunjukkan oleh warna menjadi daya tarik yang penting. Selain itu informasi harga, bagaimana sekarang kondisi persaingan antara penyedia layanan telepon seluler menyebabkan harga selalu dikorbankan untuk menarik konsumen. Informasi harga pada akhirnya dapat menentukan keputusan konsumen dalam menggunakan suatu layanan jasa atau barang.

\section{KESIMPULAN DAN SARAN}

\subsection{Kesimpulan}

1. Hasil penelitian ini menunjukkan ada variasi persepsi masyarakat etnis Sasak yang tinggal di Kota Mataram terhadap iklan Kartu As Telkomsel yang bernuansa Sasak.

2. Dari hasil penerapan metode kualitatif, mulai dari wawancara, focus group discussion, hingga workshop dapat diidentifikasi Atribut Desain iklan Kartu As yang bernuansa Budaya Sasak di Kota Mataram yaitu 1) Warna; 2) Gambar; 3) Informasi fitur dan fasilitas; 4) Slogan; 5) Informasi Harga; 6) Ukuran; 7) Media Iklan dan 8) Lokasi Iklan.

\subsection{Saran}

\subsubsection{Untuk Pemasar}

Dalam membuat iklan perusahaan memahami stimulus-stimulus yang Menarik perhatian pasar sesuai dengan hasil penelitian ini. Berikut ini sejumlah atribut Iklan Kartu As yang nantinya perlu menjadi perhatian bagi pemasar dalam menstimulus pasar.

a. Warna, hasil penelitian ini menyarankan sebaiknya pemasar dalam menentukan warna Mengikuti Warna Khas Perusahan dengan kontras yang jelas;

b. Gambar yang ditempatkan dalam iklan terkait dengan positioning sebagai "Kartunya orang Lombok" perlu ada variasi antara gambar budaya dan Alam Pulau Lombok; 


\section{JMM UNRAM

c. Informasi fitur dan fasilitas fitur utama dan tambahannya; dalam kasus informasi yang disajikan oleh iklan Kartu As, perlu dipertimbang untuk tidak sekedar mempromosi fasilitas utama, tetapi fasilitas tambahan yang mungkin diberikan kepada konsumen;

d. Slogan sebaiknya Terkait dengan identitas Pulau Lombok sehingga faktor emosional kedaerahan dapat disentuh;

e. Informasi Harga Jelas Di Setiap Fitur Yang Dipromosikan, ini berarti setiap fitur layanan memiliki penjelasan biaya dalam iklan. Ini memudahkan konsumen untuk menganggarkan dananya.

f. Ukuran, Media Iklan dan Lokasi Iklan merupakan tiga hal yang berkaitan satu dengan lainnya. Media Iklan berupa papan iklan yang besar dan terletak di lokasi yang padat penduduk memudahkan calon konsumen untuk mengamati dan selanjutnya tertarik terhadap iklan.

\subsubsection{Untuk Peneliti Selanjutnya}

Kekurangan dari penelitian ini adalah kurangnya penelitian terdahulu yang membahwa desain iklan dari sisi konsumen sehingga wawasan peneliti kurang terhadap bahasan penelitian ini. Di sisi lain penelitian ini kurang komprehensif dalam membanding desain iklan dengan iklan pesaing, untuk itu Penelitian ini sangat mungkin untuk dilanjutkan dengan penelitian yang membandingkan iklan perusahaan yang satu dengan yang lain.

\section{DAFTAR PUSTAKA}

Anomin, (2012), Sejarah Telkomsel, http://www.telkomsel.com/, diunduh 22 November 2012

Anomin, (2011), Data Kependudukan Kota Mataram 2009, http://ntb.bps.go.id/, diunduh 22 Maret 2011

Anomin, (2011), Kota Mataram 2009, http://id.wikipedia.org/wiki/Kota_Mataram, diunduh 22 Maret 2011

Arnould, E. J. (2006) Consumer culture theory: retrospect and prospect, . European Advances in Consumer Research 7 (1): 605-607. http://www.acrwebsite.org /volumes/eacr/vol7/ EuropeanVolume7_105.pdf. diunduh 14 Agustus 2010.

Arnould, E. J.; and Thompson, C. J. (2005), Consumer culture theory (CCT): Twenty Years of Research, Journal of $\quad$ Consumer $\quad$ Research $31 \quad$ (4): 882.http:/ /econpapers.repec.org/article/ucpjconrs/v_3a31_3ay_ 3a2005_3ai_3a4_3ap_3a868882.htm.

Blackwell, R., Miniard. P.W., and Engel, J. (1995) Perilaku Konsumen (F.X. Budiyanto, Trans), Jakarta: Binarupa Aksara

Byrne, J. and Humble, A. M. (2007), An Introduction to Mixed Method Research, Atlantic Researh Centre for Family-Work Issues, Mount Saint Vincent University

Cannon, H. M. and Boglarsky, C. (1992), Simulating Qualitative Research Relating to Values and Lifestyle Segmentation, Developments In Business Simulation and Experiential Exercises, Volume 19, 199233-38

Chaharsoughi, S. A. and Yasory, T. H. (2012), Effect of sales promotion on consumer behavior based on culture, African Journal of Business Management Vol. 6(1), pp. 98-102,11 January, 2012 http:/ / www.academicjournals.org/AJBM diunduh tanggal 19 Maret 2012 
Chan, A. M. (2009), Measuring Cross-Cultural Values: A Qualitative Approach International Review of Business Research Papers Vol.5, No.6 November 2009, Pp. 322-337

Cooper, Donald and Schindler, Pamela S (2001), Business Research Methods, $7^{\text {h }}$ ed. New York: McGraw Hill Inc.

Craven, D. W, (2000), Strategic Marketing, Irwin, Mc Graw Hill.

Creswell, J. W. (2007) Qualitative inquiry and research design: Choosing among five approaches, $2^{\text {rd }}$ Edition, Thousand Oaks, CA: SAGE Publications.

Creswell, J. W. (2006). Research design. Qualitative, quantitative, and mixed methods approaches. $3^{\text {rd }}$ Edition, Thousand Oaks, CA: SAGE Publications.

Dharmmesta, B. S., dan Irawan (2001), Manajemen Pemasaran Modern, Edisi Kedua, Yogyakarta, Liberty Offset.

Green, Paul E., dan Srinivasan, V.(1990), Conjoint Analysis in Marketing: New Developments with Implications for Research and Practice, Journal of Marketing; Oct 1990; 54, 4;

Jaelani, E., (2009), Marketing Mix, 12 Maret 2009 http://e-je.blogspot.com/2009/03/marketing-mix.html diunduh tanggal 19 Maret 2012

Johnson, E. M., (2002) Fundamentals of Marketing, Fourth Edition, American Management Association www.flexstudy.com/demo/.../99037_toc.pdf. diunduh tanggal 19 Maret 2012

Kotler, P. dan Keller, K. L. (2006), Marketing Management, 13th ed. New Jersey: Prentice Hall International Inc.

Kotler, P. (2003), Marketing Management, 11th ed, New Jersey: Prentice Hall International Inc.

Kotler, P. dan Armstrong, G. (2001). Principle of marketing, 7th ed. New Jersey: Prentice Hall, Inc.

Kotler, P. (2000), Marketing Management, Millennium ed. New Jersey: Prentice Hall International Inc.

Lungkang, M. J., (2008), Restrukturisasi Kredit Modal Kerja Umum dan Konstruksi Pada Pt. Bank XYZ, lontar.ui.ac.id, diunduh 1 Desember 2012

Miles, M.S. \& Hubermen, A.M. (1984), Qualitative data analysis: a sourcebook of mew method. Beverly Hills: Sage Publications.

Moleong, J.L. (2002), Metodologi penelitian kualitatif. Bandung: Remaja Rosdakarya.

Nasution, S. (1988), Metodologi penelitian naturalistik-kualitatif, Bandung: Tarsito.

Rinuastuti, B. H. dan Rusdan (2008), Analisis Dimensi Ekuitas Merek Sepeda Motor Honda Dan Yamaha Serta Pengaruhnya Terhadap Nilai Pelanggan Di Kota Mataram, Jurnal Riset Manajemen, Maret 2008

Wibisono, D., (2000), Riset Bisnis edisi pertama, BPFE, Yogyakarta

Zeithaml, V. A, and Bitner, M. J., (2003), Services Marketing: Integrating Customer focus across the firm, International Edition 2006, Mc Graw Hill, Singapore 